Gazi University
Journal of Science
PART C: DESIGN AND TECHNOLOGY
http://dergipark.gov.tr/gujsc

\title{
A New Integrated Approach for Determination of Turkey's Solar Energy Production Strategies: The Fuzzy Expanded SWOT
}

\author{
Buket KARATOP ${ }^{1}$ (D) Buşra TAŞKAN ${ }^{2 *}$ (D) \\ ${ }^{1}$ İstanbul University Cerrahpaşa Vocational School of Technical Sciences, Department of Motor Vehicles and Transportation Technologies, \\ 34500, Buyukcekmece/ISTANBUL \\ ${ }^{2}$ Muş Alparslan University Faculty of Engineering and Architecture, Department of Mechanical Engineering, 49250, Merkez/MUS
}

\section{Article Info \\ Research article \\ Received:27.07.2021 \\ Revision:04.10.2021 \\ Accepted:09.11.2021}

\section{Keywords}

Solar Energy

Strategy

SWOT

Expanded SWOT

Fuzzy AHP

Renewable energy

\begin{abstract}
Solar energy is one of the most important renewable energy types which are invested in Turkey because the country has high solar energy potential due to its geographical location and solar energy has apparent advantages. Due to the current importance of the issue, determining the strategies related to Turkey's solar energy production is aimed in this study. For this, a new integrated method called the Fuzzy Expanded SWOT which consists of the Fuzzy AHP and the Expanded SWOT methods has been proposed. The proposed method eliminates many disadvantages of the traditional SWOT analysis. First of all, factors and sub-factors related to solar energy were determined using the Expanded SWOT analysis. Subsequently, the local weights of these factors and sub-factors were determined using the Fuzzy AHP method. The sub-factors which are insignificant according to the weights found were eliminated and the global weights of the remaining sub-factors were found. Sub-factors were prioritized according to their global weights and strategies were determined according to the Expanded SWOT matrix considering these priorities. Finally, the sensitivity analysis has been performed to see the effect of the different weights given to the SWOT factors on the strategies created. As a result of the analyzes, a total of 9 strategies have been determined and it was observed that the strategies which should be dwelled on related to solar energy production in Turkey, are ones that concentrate on R\&D studies in public institutions, private sector, and universities. According to the sensitivity analysis which is performed for 3 additional scenarios, it was seen that the weights of the SWOT factors changed the direction of the strategies.
\end{abstract}

\section{INTRODUCTION}

The increasing energy need in the world due to factors technological developments, industrialization, population growth, etc., and fossil resources' inability to meet this need due to the limited availability of them in nature, have accelerated the search for alternative energy resources. Although renewable energy was used before the first industrial revolution, it has become so popular today due to the growing concerns about the security of energy supply, being environmentally friendly, and its positive economic effects. Henrik Lund [1] defined renewable energy as "energy that is produced by natural resources - such as sunlight, wind, rain, waves, tides, and geothermal heat - that are naturally replenished within a period time of a few years". Types of renewable energy are hydropower, solar energy, wind energy, geothermal energy, bioenergy (biomass, biogas, biodiesel-bioethanol), and ocean energy.

Solar energy is used worldwide for electricity generation or heating and desalinating of water and is becoming more popular day by day. Energy can be obtained directly from the sun even in cloudy weather. Solar power is mainly produced in two ways: Photovoltaics (PV) and Concentrated Solar Power (CSP) [2]. Solar energy has features such as ease of installation and use, as well as not polluting the environment and not creating hazardous waste. Turkey has a high solar energy potential due to its geographical location. According to Turkey's Solar Energy Potential Atlas (GEPA), it was determined that the annual 
total sunshine duration is 2,741 hours (daily average 7.5 hours), the annual total incoming solar energy is $1,527 \mathrm{kWh} / \mathrm{m}^{2}$.year (daily average $4.18 \mathrm{kWh} / \mathrm{m}^{2}$.day) [3].

256829 ktoe of the 13558111 ktoe total energy supply of the world in 2017 was met from wind, solar, etc. energy sources [4]. 67442 ktoe of the 1996569 ktoe total energy supply in 2017 of the European region which also contains Turkey, was met from wind, solar, etc. energy sources. In Turkey, 10170 ktoe of the 146847 ktoe total energy supply in 2017 was met from wind, solar, etc. energy sources [5]. Republic of Turkey Minister of Energy and Natural Resources expressed the current situation related to Turkey's solar energy with these words; Today, Turkey reached up to sixth row in Europe and thirteenth row in the world in terms of its installed capacity for renewable energy. Turkey has covered a very long distance about the solar energy. Until 10 years ago, while our installed solar power was zero, we have reached 6032 MW today. As of the end of January 2020, the share of solar energy got up to 6.6 percent in our total installed power and to 13.5 percent in our renewable energy installed power. Today, we are the sixth in Europe and the twelfth in the World at the installed solar power. I believe that Turkey's position will continue to grow with our new YEKA competitions [6].

In this study, it is aimed to determine the solar energy production strategies of Turkey because of the importance the country attaches to the subject and the high solar energy potential it has. The study which is structured based on this purpose consists of 5 sections, including the introduction. In the second part of the study, the literature related to the subject was mentioned. In the third part, Fuzzy AHP and Expanded SWOT methods, which constitute the new Fuzzy Expanded SWOT approach proposed in the study, were mentioned. In the fourth part, the proposed model was briefly mentioned and Turkey's solar energy production strategies were determined by making necessary analyses. In the final part, the results were interpreted and the study was completed.

\section{LITERATURE REVIEW}

An important tool to determine strategies at the strategic management process, SWOT analysis is applied to real-life problems. The most characteristic features of real-life problems are that they are uncertain and multi-criteria. For this reason, there are many studies that have used multi-criteria decision making (MCDM) methods and SWOT analysis together. Kajanus et. al [7] applied a combination of AHP, which is an MCDM technique, and SWOT analysis in their study. Later, Kangas et. al [8] integrated the AHP into SWOT, naming it A'WOT analysis. Apart from these, there are many articles ([9-24]) using SWOT analysis and MCDM methods in combination.

There are contradictions in the SWOT analysis. Depending on the perspective, a strength may also be a weakness, and an opportunity may also be a threat. Ghazinoory et. al [25] stated that it is necessary to use fuzzy sets in such uncertain situations. Therefore, in the related literature, there are also studies using Fuzzy MCDM techniques, as well as MCDM techniques along with SWOT analysis. Kheirkhah et. al [26] developed and applied a fuzzy SWOT approach to create strategies aimed at reducing the dangers related to the transport of hazardous substances in Iran. Hosseini-Nasab et. al [27] used fuzzy SWOT analysis to overcome the imprecisions in strategic planning. Sevkli et. al [28] proposed a fuzzy ANP based SWOT approach to determine the strategies related to domestic operations of Turkish airlines. The authors compared the results obtained by solving the same example with AHP, Fuzzy AHP, and ANP methods. Yapici Pehlivan et. al [29] proposed an integrated Fuzzy MCDM methodology consisting of Fuzzy AHP, WASPAS-F, EDAS-F, and ARAS-F methods, to develop organizational strategies. There are many other examples of fuzzy SWOT studies. The general opinion among researchers is that conventional SWOT analysis is inadequate in solving real-life problems. There are shortcomings in the strategy set created with the classic SWOT working according to Aristotelian logic, but good results are obtained with the fuzzy SWOT.

Since problems related to energy planning are complex, MCDM has proven to be an effective tool for solving such problems. Different MCDM techniques are applied in the renewable energy field [30]. Therefore, there are many articles employing SWOT and MCDM methods together to develop the strategies for renewable energy in the literature. Terrados et. al [31] designed a sustainable energy model focusing on renewable energy especially solar energy and biomass energy, for regional energy planning. The authors stated that the use of MCDM alone is not sufficient for strategies in energy planning, and it 
gives more meaningful results together with SWOT. Catron et. al [32] used an integrated SWOT-ANP approach in the development of energy policies. In the study evaluating the development of bioenergybased energy production, the ANP method was used because bioenergy factors are related to each other. Kabak and Dağdeviren [33] used the BOCR (Benefits, Opportunities, Costs, and Risks) method which is a similar analysis to SWOT, integrated with ANP at the evaluation of renewable energy in Turkey. In the study, 5 renewable energy sources (Hydropower, Geothermal, Solar, Wind, and Biomass) were evaluated according to 19 criteria. Adar et. al [34] have proposed an integrated model consisting of Fuzzy AHP and MCDM methods for sustainable energy management strategies in Turkey. The authors identified 4 main criteria and 20 sub-criteria and they ranked the main and sub-criteria according to their importance degrees. Kabak et. al [35] established the MCDM hierarchy between the SWOT main factors (4 criteria) and sub-factors (29 sub-criteria) to determine the renewable energy policies in Turkey. In this hierarchy, the relationships between factors were evaluated with the Fuzzy ANP. Sindhu et. al [36] prioritized the factors determined by Strength-Weakness-Opportunity-Challenges (SWOC) analysis with the AHP method to assist policy planners in their studies where they emphasized the importance of solar energy for a sustainable future. Ervural et. al [37] used the ANP and Fuzzy TOPSIS based SWOT analysis for the determination of policies related to the energy sector in Turkey. Khan [38] used an integrated SWOTFuzzy MCDM method to evaluate the strategies of the compressed natural gas (CNG) industry. A modified fuzzy goal programming was used as the fuzzy MCDM method. Solangi et. al [39] used AHP and fuzzy TOPSIS based SWOT analysis to determine energy strategies. They weighted the SWOT factors and sub-factors with the AHP and ranked energy strategies with the Fuzzy TOPSIS. Alizadeh et al. [40] proposed a framework for the formulation of policies regarding renewable energy. A hybrid MCDM method consisting of BOCR and ANP was used in the study. MCDM and SWOT (or similar analyzes) have been integrated into with the articles mentioned up to now. Strategies or policies were tried to be determined only through ranking and prioritization.

\section{RESEARCH METHODOLOGY}

In this study, a new approach which is called Fuzzy Expanded SWOT and eliminates some of the shortcomings of the SWOT analysis is proposed. Firstly, the Expanded SWOT method was developed by looking at the SWOT analysis from a wider perspective. Then, by integrating the Fuzzy AHP method into the Expanded SWOT method, the Fuzzy Expanded SWOT approach used in the study was obtained.

\subsection{The Fuzzy AHP Method}

Although the AHP method is very popular and widely used in applications, it may not reflect the way people think exactly [41]. The fuzzy AHP method has been developed to overcome the mentioned deficiency of the AHP method. Although there are various fuzzy AHP methods in the literature such as Van Laarhoven and Pedrycz Fuzzy AHP method, Buckley Fuzzy AHP method, Chang's Extended Analysis method [42], Chang's Extended Analysis method was preferred in this study. Because this method has advantages such as requiring less computation, following the steps of traditional AHP, and not requiring additional processing [43]. The method was described in detail below [44];

Let $X=\left\{x_{1}, x_{2}, \ldots \ldots, x_{n}\right\}$ be a criterion set and $G=\left\{g_{1}, g_{2}, \ldots \ldots, g_{m}\right\}$ be an objective set. In this method, each criterion is taken and an extent analysis is performed for each purpose. Thus, $\mathrm{m}$ extent analysis values are obtained for each criterion. These are shown as $M_{g_{i}}^{1}, M_{g_{i}}^{2}, \ldots \ldots, M_{g_{i}}^{m} i=1,2, \ldots \ldots n$ and all the $M_{g_{i}}^{j}(j=1,2, \ldots \ldots m)$ values are triangular fuzzy numbers (TFNs).

Step 1: According to criterion i, fuzzy synthetic extent values (Si) are determined using Eq. (1);

$$
S_{i}=\sum_{j=1}^{m} M_{g_{i}}^{j} *\left[\sum_{i=1}^{n} \sum_{j=1}^{m} M_{g_{i}}^{j}\right]^{-1}
$$

The fuzzy addition operation is performed on M values by using Eq. (2) to obtain $\sum_{j=1}^{m} M_{g_{i}}^{j}$ in the Eq. $(1)$; 
$\sum_{j=1}^{m} M_{g_{i}}^{j}=\left(\sum_{j=1}^{m} l_{j}, \sum_{j=1}^{m} m_{j}, \sum_{j=1}^{m} u_{j}\right)$

To obtain $\left[\sum_{i=1}^{n} \sum_{j=1}^{m} M_{g_{i}}^{j}\right]^{-1}$ in the Eq. (1), Eq. (3) and Eq. (4) are used;

$\sum_{i=1}^{n} \sum_{j=1}^{m} M_{g_{i}}^{j}=\left(\sum_{i=1}^{n} l_{i}, \sum_{i=1}^{n} m_{i}, \sum_{i=1}^{n} u_{i}\right)$

$\left[\sum_{i=1}^{n} \sum_{j=1}^{m} M_{g_{i}}^{j}\right]^{-1}=\left(\frac{1}{\sum_{i=1}^{n} u_{i}}, \frac{1}{\sum_{i=1}^{n} m_{i}}, \frac{1}{\sum_{i=1}^{n} l_{i}}\right)$

Step 2: The possibility degree for $M_{2}=\left(l_{2}, m_{2}, u_{2}\right) \geq M_{1}=\left(l_{1}, m_{1}, u_{1}\right)$ is expressed as $\mathrm{V}\left(M_{2} \geq\right.$ $\left.M_{1}\right)=\sup _{y \geq x}\left[\min \left(\mu_{M_{1}}(x), \mu_{M_{2}}(y)\right)\right]$. If this equation is analyzed, the Eq. (5) is obtained;

$V\left(M_{2} \geq M_{1}\right)=\operatorname{hgt}\left(M_{1} \cap M_{2}\right)=\mu_{M_{2}}(d)=\left\{\begin{array}{lr}1, & \text { if } m_{2} \geq m_{1}, \\ 0, & \text { if } l_{1} \geq u_{2}, \\ \frac{l_{1}-u_{2}}{\left(m_{2}-u_{2}\right)-\left(m_{1}-l_{1}\right)}, & \text { otherwise },\end{array}\right.$

In Eq. (5), $d$ is the ordinate of the highest intersection point between $\mu_{M_{1}}$ and $\mu_{M_{2}}$. To compare $M_{1}$ and $M_{2}$ values, both $V\left(M_{2} \geq M_{1}\right)$ and $V\left(M_{1} \geq M_{2}\right)$ values must be known.

Step 3: The possibility degree of a convex number being greater than $\mathrm{k}$ convex fuzzy numbers $\left(M_{i} i=\right.$ $\{1,2, \ldots, k\})$ must also be considered.

$V\left(M \geq M_{1}, \ldots, M_{k}\right)=V\left[\left(M \geq M_{1}\right)\right.$ ve $\left(M \geq M_{2}\right)$ ve $\ldots$ ve $\left.\left(M \geq M_{k}\right)\right]=\min V\left(M \geq M_{1}\right)$

In Eq. (6), if $d^{\prime}\left(A_{i}\right)=\min V\left(S_{i} \geq S_{k}\right)$ for $\mathrm{i}=\{1,2, \ldots, k\}$, weight vectors for $\mathrm{k} \neq i$ are calculated using Eq. (7) as the following;

$W^{\prime}=\left(d^{\prime}\left(A_{1}\right), d^{\prime}\left(A_{2}\right), \ldots, d^{\prime}\left(A_{n}\right)\right)^{T} \quad i=\{1,2, \ldots, n\}$

Step 4: The weight vectors are normalized using Eq. (8);

$W=\left(d\left(A_{1}\right), d\left(A_{2}\right), \ldots, d\left(A_{n}\right)\right)^{T} \quad i=\{1,2, \ldots, n\}$

In Eq. (8), the W weight vector isn't a fuzzy number. The final alternative weights are found by hierarchically synthesizing obtained these weights. 


\subsection{A New Approach to the SWOT Analysis: The Expanded SWOT Analysis}

In general, the strategic direction or strategies of an individual, an event, and a company are determined based on its current situation. The current situation consists of the individual, the event, the company itself, and the environment in which it is located. The individual, event, or company has its advantages (strengths) and disadvantages (weaknesses) whilst its environment incorporates advantages (opportunities) and disadvantages (threats). These advantages and disadvantages of the individual, the event, or the company in itself and its environment, are determined by SWOT analysis. Strategies are important decisions in shaping the future of companies. The accuracy of these decisions is ensured with analytical methods and analyzes. SWOT analysis is an important analysis in the creation of strategies and it must be said that the strategies determined without considering the mission, vision, core values, and stakeholder views are missing. SWOT analysis was developed in the 1960s [45] and was popularized by Andrews (1965), who combined the ideas of Peter Drucker, Philip Selznick, and Alfred Chandler [28].

David [46] stated that the 4 group strategies created as a result of SWOT analysis are StrengthsOpportunities (SO) strategies, Weaknesses-Opportunities (WO) strategies, Strengths-Threats (ST) strategies, Weaknesses-Threats (WT) strategies. Sevkli et. al [28] described these strategies which are also seen in Figure 1, as follows: "SO strategies use a firm's internal strengths to take advantage of external opportunities. WO strategies improve internal weaknesses by taking advantage of external opportunities. ST strategies use a firm's strengths to avoid or reduce the impact of external threats. WT strategies are defensive tactics directed at reducing internal weaknesses and avoiding environmental threats". According to Hill and Westbrook [47], some criticisms towards SWOT analysis are as follows; creating extremely long lists, not using weights to reflect priorities, using ambiguous words and expressions, conflicts have no solution, there is no obligation to verify thoughts by data or analysis, it requires only one level of analysis, there is no logical link to strategy implementation.

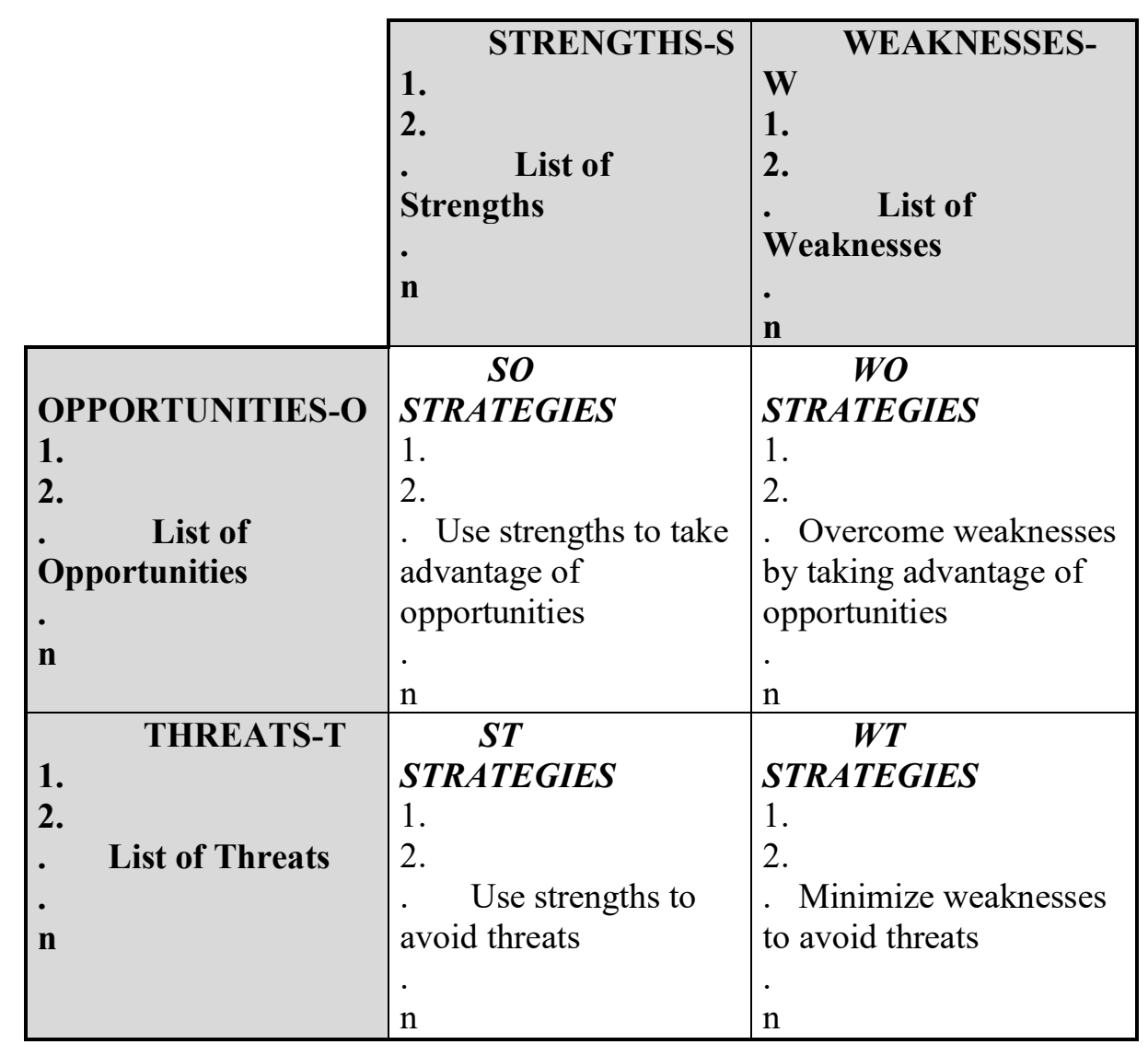

Figure 1. A generic presentation of the SWOT matrix [28] 
In this study, by evaluating the SWOT matrix from a wider perspective, the matrix called Expanded SWOT in Figure 2 was developed. While there are 4 general groups of strategies in the SWOT matrix, there are 16 more detailed groups of strategies in the expanded SWOT matrix. Although some of these strategy groups obtained with the method seem very similar to each other, in this way there is no overlooked strategy.

\begin{tabular}{|c|c|c|c|c|}
\hline & $\begin{array}{l}\text { STRENGTHS-S } \\
1 . \\
2 . \\
\text { Strengths } \\
\text { n } \\
\end{array}$ & $\begin{array}{l}\text { WEAKNESSES- } \\
\text { W } \\
1 . \\
2 . \\
\text { List of } \\
\text { Weaknesses } \\
\text { n }\end{array}$ & $\begin{array}{l}\text { OPPORTUNITIES- } \\
\text { O } \\
1 . \\
2 . \\
\text { Opist of } \\
\text { Opportunities } \\
\text { n }\end{array}$ & 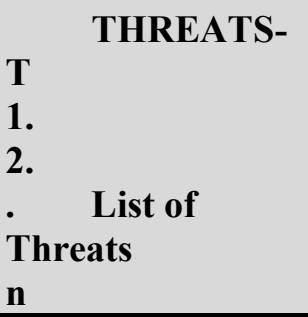 \\
\hline $\begin{array}{l} \\
1 . \\
2 . \\
\text { STRENGTHS-S } \\
\text { Strengths } \\
\text { n }\end{array}$ & SS STRATEGIES & $\begin{array}{c}\text { SW } \\
\text { STRATEGIES }\end{array}$ & SO STRATEGIES & ST STRATEGIES \\
\hline $\begin{array}{l}\text { WEAKNESSES- } \\
\text { W } \\
1 . \\
\text { 2. } \\
\text { List of } \\
\text { Weaknesses } \\
\text { n }\end{array}$ & $\begin{array}{c}\text { WS } \\
\text { STRATEGIES }\end{array}$ & $\begin{array}{c}\text { WW } \\
\text { STRATEGIES }\end{array}$ & WO STRATEGIES & $\begin{array}{c}\text { WT } \\
\text { STRATEGIES }\end{array}$ \\
\hline $\begin{array}{l}\text { OPPORTUNITIES- } \\
\text { O } \\
1 . \\
2 . \\
\text { List of } \\
\text { Opportunities } \\
\text { n }\end{array}$ & $\begin{array}{c}\text { OS } \\
\text { STRATEGIES }\end{array}$ & $\begin{array}{c}\text { OW } \\
\text { STRATEGIES }\end{array}$ & OO STRATEGIES & OT STRATEGIES \\
\hline $\begin{array}{ll} & \text { THREATS-T } \\
\text { 1. } & \\
\text { 2. } & \\
\text {. } & \text { List of Threats } \\
\text { n } & \end{array}$ & TS STRATEGIES & $\begin{array}{c}\text { TW } \\
\text { STRATEGIES }\end{array}$ & TO STRATEGIES & TT STRATEGIES \\
\hline
\end{tabular}

Figure 2. A generic presentation of the Expanded SWOT matrix

The 16 group strategies and explanations of them created with the Expanded SWOT matrix are as follows;

Strategies created by using strengths

Strength-Strength (SS) Strategies: It is a group of strategies to increase strengths by using its other strengths.

Strength-Weakness (SW) Strategies: It is a group of strategies to strengthen weaknesses by using its strengths. 
Strength-Opportunity (SO) Strategies: It is a group of strategies to take advantage of the opportunities and increase them by using its strengths.

Strength-Threat (ST) Strategies: It is a group of strategies to use its strengths to remove the threats or turn them into opportunities.

\section{Strategies created by using weaknesses}

Weakness-Strength (WS) Strategies: It is a group of strategies to increase its strengths by knowing or using its weaknesses.

Weakness-Weakness (WW) Strategies: It is a group of strategies to strengthen its weaknesses by knowing or using its weaknesses.

Weakness-Opportunity (WO) Strategies: It is a group of strategies to increase and use the opportunities by knowing or using its weaknesses.

Weakness-Threat (WT) Strategies: It is a group of strategies to remove the threats or turn them into opportunities by knowing or using its weaknesses.

\section{Strategies created by using opportunities}

Opportunity-Strength (OS) Strategies: It is a group of strategies to increase its strengths by using opportunities.

Opportunity-Weakness (OW) Strategies: It is a group of strategies to strengthen its weaknesses by using opportunities.

Opportunity-Opportunity (OO) Strategies: It is a group of strategies of increasing and using opportunities by using opportunities.

Opportunity-Threat (OT) Strategies: It is a group of strategies to remove threats or turn them into opportunities by using opportunities.

Strategies created by using threats

Threat-Strength (TS) Strategies: It is a group of strategies to increase its strengths by being aware of and using the threats.

Threat-Weakness (TW) Strategies: It is a group of strategies to strengthen their weaknesses by being aware of and using threats.

Threat-Opportunity (TO) Strategies: It is a group of strategies to take advantage of opportunities and increase them by being aware of and using threats.

Threat-Threat (TT) Strategies: It is a group of strategies to remove threats or turn them into opportunities by being aware of and using threats.

\section{THE PROPOSED FUZZY EXPANDED SWOT APPROACH AND ITS APPLICATION}

The proposed model, in order to determine strategies related to the Turkey's solar energy production is as seen in Figure 3. As also mentioned in the previous section, there are some criticisms of traditional SWOT analysis. With the Fuzzy Expanded SWOT which is a new integrated approach proposed in this study, some shortcomings of the traditional SWOT analysis have been eliminated. The shortcomings mentioned and how they were eliminated were mentioned below;

$>$ No using weights to reflect priorities; This disadvantage of the traditional SWOT analysis was eliminated by determining the weights of factors and sub-factors using the Fuzzy AHP method.

$>$ Using ambiguous words and expressions; This disadvantage of the traditional SWOT analysis was eliminated by using fuzzy logic.

$>$ Creating extremely long lists; This disadvantage of the traditional SWOT analysis was eliminated by removing the sub-factors which are insignificant according to weights found with the Fuzzy AHP method, from the list.

$>$ There is no obligation to verify thoughts by data or analysis; This disadvantage of the traditional SWOT analysis was eliminated by using the Fuzzy AHP method. 
$>$ It requires only one level of analysis; This disadvantage of the traditional SWOT analysis was eliminated by increasing the number of analysis levels with the method used.

$>$ Conflicts have no solution; Since the strategies were developed in more detail with the use of Expanded SWOT analysis, this disadvantage of the traditional SWOT analysis was eliminated.

$>$ There is no logical link to strategy implementation; This disadvantage of the traditional SWOT analysis was eliminated by using the most important sub-factors in forming strategies thanks to giving weight to sub-factors. 


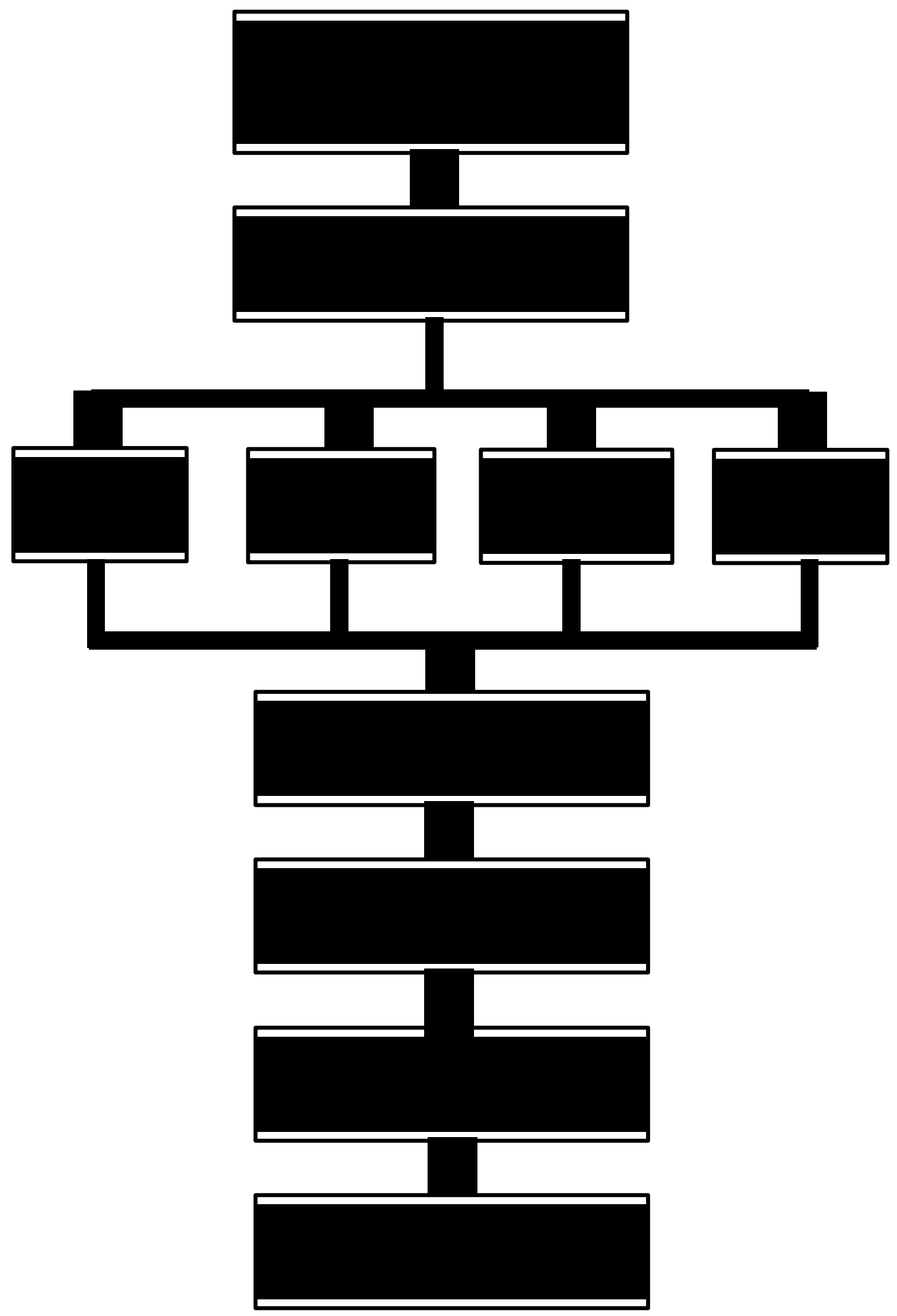

Figure 3. The general structure of the proposed model 
Application steps of the proposed method are explained below;

Step 1: Determination of the expert group

At this stage, the experts who are consulted to their opinions about the problem addressed were determined. The expert group consists of professionals working in the solar energy sector and specialized in this field.

Step 2: Application of the Expanded SWOT analysis

At this stage, Turkey's strengths and weaknesses, as well as opportunities and threats in its environmentrelated to solar energy generation were identified. For this purpose, firstly the scientific publications on solar energy production in Turkey and the strategic documents published by the Turkish government were reviewed. The first SWOT draft was formed. Then, the necessary information were obtained from the experts with the brainstorming technique and the second SWOT draft was formed. The experts were discussed again on the topic and they jointly proposed changes for the draft documents. The documents were simplified and the final version of Expanded SWOT analysis which is seen in Table 1 was created; 
Table 1. Expanded SWOT analysis related to Turkey's solar energy

\begin{tabular}{|c|c|c|}
\hline & ADVANTAGES & DISADVANTAGES \\
\hline $\begin{array}{l}\text { INTERNAL } \\
\text { FACTORS }\end{array}$ & $\begin{array}{l}\text { Strengths (S) } \\
\mathbf{S}_{\mathbf{1}} \text { : The abundant and inexhaustible resource } \\
\mathbf{S}_{\mathbf{2}} \text { : Transforming the sun into energy is easy } \\
\mathbf{S}_{\mathbf{3}} \text { : Accessing the raw material (sun) is easy } \\
\mathbf{S}_{\mathbf{4}} \text { : No causing environmental pollution, in other } \\
\text { words, being environmentally friendly } \\
\mathbf{S}_{\mathbf{5}} \text { : Low maintenance cost of power plants } \\
\mathbf{S}_{\mathbf{6}} \text { : It can be used in all areas where energy is } \\
\text { needed } \\
\mathbf{S}_{\mathbf{7}} \text { : It reduces dependence on foreign sources and } \\
\text { ensures the security of supply } \\
\mathbf{S}_{\mathbf{8}} \text { : It is possible to design solar energy production } \\
\text { systems to meet energy needs on a small or large } \\
\text { scale } \\
\mathbf{S}_{\mathbf{9}} \text { : Solar panels increase production power and } \\
\text { efficiency } \\
\mathbf{S}_{\mathbf{1 0}} \text { : It is sustainable }\end{array}$ & $\begin{array}{l}\text { Weaknesses (W) } \\
\mathbf{W}_{\mathbf{1}} \text { : Its investment cost is high } \\
\mathbf{W}_{\mathbf{2}} \text { : It is not possible to produce it at night } \\
\mathbf{W}_{3} \text { : It may cause the death of some animals such as birds etc. } \\
\mathbf{W}_{4} \text { : Depending on the use of solar panels used in energy production, the energy } \\
\text { production efficiency decreases by years } \\
\mathbf{W}_{5} \text { : As solar energy cannot be produced continuously there is a need for storage } \\
\text { and the storage opportunities are limited } \\
\mathbf{W}_{6} \text { : There should be no shade around production plants to allow them to fully } \\
\text { capture the sun. Therefore, the plants should be installed in a full open area } \\
\mathbf{W}_{7} \text { : The amount of energy produced in solar power plants requires much more } \\
\text { space compared to the same amount of energy produced in other types of power } \\
\text { plants }\end{array}$ \\
\hline $\begin{array}{l}\text { EXTERNAL } \\
\text { FACTORS }\end{array}$ & $\begin{array}{l}\text { Opportunities (O) } \\
\mathbf{O}_{1} \text { : The number of sunny days is high } \\
\mathbf{O}_{2} \text { : There are suitable lands for power plant } \\
\text { installation } \\
\mathbf{O}_{3} \text { : It can be used more widely with the rapid } \\
\text { development of technology } \\
\mathbf{O}_{4} \text { : It offers financial gain to investors in the } \\
\text { short-term } \\
\mathbf{O}_{5} \text { : Awareness about renewable energy has begun to } \\
\text { occur } \\
\mathbf{O}_{6}: \text { There is an increase in the number of domestic } \\
\text { engineering firms and investments made in the } \\
\text { renewable energy sector }\end{array}$ & $\begin{array}{l}\text { Threats }(\mathbf{T}) \\
\mathbf{T}_{\mathbf{1}}: \text { The quality of sun rays varies depending on the season } \\
\mathbf{T}_{2}: \text { It is difficult and expensive to obtain land in the regions where there are no } \\
\text { suitable lands (empty). } \\
\mathbf{T}_{3}: \text { The incentives offered by the laws are not enough } \\
\mathbf{T}_{4}: \text { Limiting of power plant installation due to the capacity filling problem in } \\
\text { transformer stations } \\
\mathbf{T}_{5}: \text { The power of transformer stations cannot be increased due to the lack of } \\
\text { adequate capacity and thus the production is limited } \\
\mathbf{T}_{6}: \text { Realization of the legal process, permissions, and project approvals in the long } \\
\text { term }\end{array}$ \\
\hline
\end{tabular}




\section{Step 3: Calculation of the weights of Expanded SWOT analysis factors and sub-factors}

At this stage, weights of Expanded SWOT analysis factors (Strengths (S), Weaknesses (W), Opportunities (O), Threats (T)) and sub-factors (Sk, Wl, Om, Tn) were calculated using Chang's Extended Analysis method. When calculating weights for each of the Expanded SWOT factors and subfactors, the geometrical means of expert opinions were obtained and one pairwise comparison matrix was obtained for each of the factors and sub-factors. For this purpose, firstly the pairwise comparisons were made for Expanded SWOT analysis factors and sub-factors by the experts according to values in Table 2;

Table 2. Values for expert evaluations [48]

\begin{tabular}{|c|c|}
\hline $\begin{array}{c}\text { Importance } \\
\text { Degrees }\end{array}$ & Linguistic Expressions \\
\hline 1 & Both factors are equally important \\
\hline 2 & 1st factor is less important than the 2nd factor. \\
\hline 3 & 1st factor being averagely important with respect to 2nd factor \\
\hline 4 & 1st factor is more important than the 2nd factor \\
\hline 5 & 1st factor is very important than the 2nd factor \\
\hline
\end{tabular}

The Expanded SWOT analysis has 4 factors as can also be seen from Table 1 . To determine the weights of factors, a pairwise comparison matrix at $4 * 4$ dimension (SWOT $4 * 4$ ) was created as a result of experts' evaluations as seen in Table 3;

Table 3. The pairwise comparison matrix for Expanded SWOT's factors

\begin{tabular}{|c|c|c|c|c|}
\cline { 2 - 5 } \multicolumn{1}{c|}{} & $\mathbf{S}$ & $\mathbf{W}$ & $\mathbf{O}$ & $\mathbf{T}$ \\
\hline $\mathbf{S}$ & 1 & 1,189 & 1,189 & 1,189 \\
\hline $\mathbf{W}$ & 0,841 & 1 & 1,074 & 1,414 \\
\hline $\mathbf{O}$ & 0,841 & 0,931 & 1 & 1,224 \\
\hline $\mathbf{T}$ & 0,841 & 0,707 & 0,816 & 1 \\
\hline
\end{tabular}

The Strengths factor has 10 sub-factors as can also be seen from Table 1. To determine the weights of related sub-factors, a pairwise comparison matrix at 10*10 dimensions (S10x10) was created as a result of experts' evaluations as seen in Table 4;

Table 4. The pairwise comparison matrix for Strengths' sub-factors

\begin{tabular}{|c|c|c|c|c|c|c|c|c|c|c|}
\cline { 2 - 12 } \multicolumn{1}{c|}{} & $\mathbf{S}_{\mathbf{1}}$ & $\mathbf{S}_{\mathbf{2}}$ & $\mathbf{S}_{\mathbf{3}}$ & $\mathbf{S}_{\mathbf{4}}$ & $\mathbf{S}_{\mathbf{5}}$ & $\mathbf{S}_{\mathbf{6}}$ & $\mathbf{S}_{\mathbf{7}}$ & $\mathbf{S}_{\mathbf{8}}$ & $\mathbf{S}_{\mathbf{9}}$ & $\mathbf{S}_{\mathbf{1 0}}$ \\
\hline $\mathbf{S}_{\mathbf{1}}$ & 1 & 0,5623 & 1 & 1 & 0,7953 & 0,5623 & 0,5373 & 0,5946 & 0,5946 & 0,5 \\
\hline $\mathbf{S}_{\mathbf{2}}$ & 1,7783 & 1 & 2,3784 & 2,2134 & 1,1247 & 3,5566 & 1,8612 & 1,5651 & 1,6818 & 0,7186 \\
\hline $\mathbf{S}_{\mathbf{3}}$ & 1 & 0,4204 & 1 & 1 & 0,5081 & 0,3976 & 0,7071 & 1,1067 & 0,8409 & 0,6687 \\
\hline $\mathbf{S}_{\mathbf{4}}$ & 1 & 0,4518 & 1 & 1 & 0,4273 & 0,6389 & 0,5623 & 0,7953 & 0,8409 & 0,6687 \\
\hline $\mathbf{S}_{\mathbf{5}}$ & 1,2574 & 0,8891 & 1,968 & 2,3403 & 1 & 1 & 1,0746 & 0,5946 & 0,4204 & 0,6223 \\
\hline $\mathbf{S}_{\mathbf{6}}$ & 1,7783 & 0,2812 & 2,5149 & 1,5651 & 1 & 1 & 2,6321 & 2,8284 & 1,3161 & 1 \\
\hline $\mathbf{S}_{\mathbf{7}}$ & 1,8612 & 0,5373 & 1,4142 & 1,7783 & 0,9306 & 0,3799 & 1 & 1,1892 & 0,5946 & 0,5373 \\
\hline $\mathbf{S}_{\mathbf{8}}$ & 1,6818 & 0,6389 & 0,9036 & 1,2574 & 1,6818 & 0,3536 & 0,8409 & 1 & 0,9457 & 0,3593 \\
\hline $\mathbf{S}_{\mathbf{9}}$ & 1,6818 & 0,5946 & 1,1892 & 1,1892 & 2,3784 & 0,7598 & 1,6818 & 1,0574 & 1 & 0,7186 \\
\hline $\mathbf{S}_{\mathbf{1 0}}$ & 2 & 1,3916 & 1,4953 & 1,4953 & 1,6069 & 1 & 1,8612 & 2,7832 & 1,3916 & 1 \\
\hline
\end{tabular}


The Weaknesses factor has $7 \mathrm{sub}$-factors as can also be seen from Table 1. To determine the weights of related sub-factors, a pairwise comparison matrix at $7 * 7$ dimension $\left(\mathrm{W}_{7 \times 7}\right)$ was created as a result of experts' evaluations as seen in Table 5;

Table 5. The pairwise comparison matrix for Weaknesses' sub-factors

\begin{tabular}{|l|c|c|c|c|c|c|c|}
\cline { 2 - 9 } \multicolumn{1}{c|}{} & $\mathbf{W}_{\mathbf{1}}$ & $\mathbf{W}_{\mathbf{2}}$ & $\mathbf{W}_{\mathbf{3}}$ & $\mathbf{W}_{\mathbf{4}}$ & $\mathbf{W}_{\mathbf{5}}$ & $\mathbf{W}_{\mathbf{6}}$ & $\mathbf{W}_{\mathbf{7}}$ \\
\hline $\mathbf{W}_{\mathbf{1}}$ & 1 & 3,1623 & 4,7287 & 4,4006 & 1,6069 & 2,3403 & 2,1147 \\
\hline $\mathbf{W}_{\mathbf{2}}$ & 0,3162 & 1 & 2,9428 & 0,7477 & 0,4273 & 0,3593 & 0,3593 \\
\hline $\mathbf{W}_{\mathbf{3}}$ & 0,2115 & 0,3398 & 1 & 0,2541 & 0,2236 & 0,3593 & 0,2812 \\
\hline $\mathbf{W}_{\mathbf{4}}$ & 0,2272 & 1,3375 & 3,936 & 1 & 0,5081 & 0,8801 & 1,4142 \\
\hline $\mathbf{W}_{\mathbf{5}}$ & 0,6223 & 2,3403 & 4,4721 & 1,968 & 1 & 2,1147 & 1,6818 \\
\hline $\mathbf{W}_{\mathbf{6}}$ & 0,4273 & 2,7832 & 2,7832 & 1,1362 & 0,4729 & 1 & 0,5946 \\
\hline $\mathbf{W}_{\mathbf{7}}$ & 0,4729 & 2,7832 & 3,5566 & 0,7071 & 0,5946 & 1,6818 & 1 \\
\hline
\end{tabular}

The Opportunities factor has 6 sub-factors as can also be seen from Table 1. To determine the weights of related sub-factors, a pairwise comparison matrix at $6^{*} 6$ dimension $\left(\mathrm{O}_{6 \times 6}\right)$ was created as a result of experts' evaluations as seen in Table 6;

Table 6. The pairwise comparison matrix for Opportunities'sub-factors

\begin{tabular}{|l|c|c|c|c|c|c|}
\cline { 2 - 7 } \multicolumn{1}{c|}{} & $\mathbf{O}_{\mathbf{1}}$ & $\mathbf{O}_{\mathbf{2}}$ & $\mathbf{O}_{\mathbf{3}}$ & $\mathbf{O}_{4}$ & $\mathbf{O}_{\mathbf{5}}$ & $\mathbf{O}_{\mathbf{6}}$ \\
\hline $\mathbf{O}_{\mathbf{1}}$ & 1 & 1,7783 & 0,7953 & 0,7186 & 0,6043 & 0,9306 \\
\hline $\mathbf{O}_{\mathbf{2}}$ & 0,5623 & 1 & 0,273 & 0,5373 & 0,7186 & 0,6389 \\
\hline $\mathbf{O}_{3}$ & 1,2574 & 3,6628 & 1 & 1,968 & 1,1067 & 1,1892 \\
\hline $\mathbf{O}_{4}$ & 1,3916 & 1,8612 & 0,5081 & 1 & 1,3375 & 0,6043 \\
\hline $\mathbf{O}_{5}$ & 1,6549 & 1,3916 & 0,9036 & 0,7477 & 1 & 1,6549 \\
\hline $\mathbf{O}_{\mathbf{6}}$ & 1,0746 & 1,5651 & 0,8409 & 1,6549 & 0,6043 & 1 \\
\hline
\end{tabular}

The Threats factor has 6 sub-factors as can also be seen from Table 1. To determine the weights of related sub-factors, a pairwise comparison matrix at $6 * 6$ dimension $(\mathrm{T} 6 \times 6)$ was created as a result of experts' evaluations as seen in Table 7;

Table 7. The pairwise comparison matrix for Threats' sub-factors

\begin{tabular}{|c|c|c|c|c|c|c|}
\cline { 2 - 7 } \multicolumn{1}{c|}{} & $\mathbf{T}_{\mathbf{1}}$ & $\mathbf{T}_{\mathbf{2}}$ & $\mathbf{T}_{\mathbf{3}}$ & $\mathbf{T}_{\mathbf{4}}$ & $\mathbf{T}_{\mathbf{5}}$ & $\mathbf{T}_{\mathbf{6}}$ \\
\hline $\mathbf{T}_{\mathbf{1}}$ & 1 & 0,3861 & 0,2115 & 0,3761 & 0,4472 & 0,2115 \\
\hline $\mathbf{T}_{\mathbf{2}}$ & 2,59 & 1 & 0,7186 & 0,4273 & 0,4273 & 0,2515 \\
\hline $\mathbf{T}_{\mathbf{3}}$ & 4,7287 & 1,3916 & 1 & 0,7071 & 0,7071 & 0,5373 \\
\hline $\mathbf{T}_{\mathbf{4}}$ & 2,6591 & 2,3403 & 1,4142 & 1 & 1 & 0,6687 \\
\hline $\mathbf{T}_{\mathbf{5}}$ & 2,2361 & 2,3403 & 1,4142 & 1 & 1 & 0,6687 \\
\hline $\mathbf{T}_{\mathbf{6}}$ & 4,7287 & 3,9764 & 1,8612 & 1,4953 & 1,4953 & 1 \\
\hline
\end{tabular}

At the current stage, weight values were found for each of the Expanded SWOT analysis factors and subfactors, and then the accuracy of the results was tested with the consistency analysis. If the consistency rate (CR) obtained with consistency analysis is less than or equal to 0.10 , the related result is consistent. Factors and sub-factors were prioritized by interpreting the obtained results. Firstly, the weight values of the factors seen in Table 8 were calculated and the consistency analysis was performed. Because $C R=$ $0,00365 \leq 0,10$, the obtained results are consistent. From the results, it was seen that the most important factor is Strengths $(\mathrm{S})$. 
Table 8. The local weights of the SWOT factors

\begin{tabular}{|c|c|c|}
\hline & $\mathbf{W}_{\mathbf{i}}$ & CR \\
\hline $\mathbf{S}$ & 0,340883 & \multirow{4}{*}{0,00365} \\
\hline W & 0,300878 & \\
\hline $\mathbf{O}$ & 0,253261 & \\
\hline $\mathbf{T}$ & 0,104978 & \\
\hline
\end{tabular}

The Strengths factor has 10 sub-factors and the local weights for each sub-factor were calculated as seen in Table 9. Because $\mathrm{CR}=0,033 \leq 0,10$, the obtained results are consistent. Since the weights of S1 and S3 are small at a negligible level, the related weight values were taken as zero in accordance with the fuzzy AHP procedure.

Table 9. The local weights of the Strengths' sub-factors

\begin{tabular}{|c|c|c|}
\hline & $\mathbf{W}_{\mathrm{i}}$ & CR \\
\hline $\mathbf{S}_{1}$ & 0 & \multirow{10}{*}{0,033} \\
\hline $\mathbf{S}_{\mathbf{2}}$ & 0,22555 & \\
\hline $\mathbf{S}_{3}$ & 0 & \\
\hline $\mathbf{S}_{4}$ & 0,062974 & \\
\hline $\mathbf{S}_{5}$ & 0,084346 & \\
\hline $\mathbf{S}_{6}$ & 0,198926 & \\
\hline $\mathbf{S}_{7}$ & 0,060601 & \\
\hline $\mathbf{S}_{8}$ & 0,067426 & \\
\hline $\mathbf{S}_{9}$ & 0,119442 & \\
\hline$S_{10}$ & 0,180736 & \\
\hline
\end{tabular}

The Weaknesses factor has $7 \mathrm{sub}$-factors and the local weights for each sub-factor were calculated as seen in Table 10. Because $C R=0,035 \leq 0,10$, the obtained results are consistent. Since the weights of $\mathrm{W}_{2}$ and $\mathrm{W}_{3}$ are small at a negligible level, the related weight values were taken as zero in accordance with the fuzzy AHP procedure.

Table 10. The local weights of the Weaknesses' sub-factors

\begin{tabular}{|c|c|c|}
\cline { 2 - 2 } \multicolumn{1}{c|}{} & $\mathbf{W}_{\mathbf{i}}$ & $\mathbf{C R}$ \\
\hline $\mathbf{W}_{\mathbf{1}}$ & 0,55018 & \multirow{1}{*}{0} \\
\cline { 1 - 2 } $\mathbf{W}_{\mathbf{2}}$ & 0 & \multirow{2}{*}{0,035} \\
\hline $\mathbf{W}_{\mathbf{3}}$ & 0 & \\
\hline $\mathbf{W}_{\mathbf{4}}$ & 0,022722 & \\
\hline $\mathbf{W}_{\mathbf{5}}$ & 0,274003 & \\
\hline $\mathbf{W}_{\mathbf{6}}$ & 0,024384 & \\
\hline $\mathbf{W}_{\mathbf{7}}$ & 0,128711 & \\
\hline
\end{tabular}

The Opportunities factor has 6 sub-factors and the local weights for each sub-factor were calculated as seen in Table 11. Because $C R=0,03 \leq 0,10$, the obtained results are consistent. Since the weight of $O 2$ is small at a negligible level, the related weight value was taken as zero in accordance with the fuzzy AHP procedure. 
Table 11. The local weights of the Opportunities' sub-factors

\begin{tabular}{|c|c|c|}
\hline & $\mathbf{W}_{\mathbf{i}}$ & $\overline{C R}$ \\
\hline $\mathbf{O}_{1}$ & 0,079308 & \multirow{6}{*}{0,03} \\
\hline $\mathbf{O}_{2}$ & 0 & \\
\hline $\mathbf{O}_{3}$ & 0,391602 & \\
\hline $\mathbf{O}_{4}$ & 0,157812 & \\
\hline $\mathbf{O}_{5}$ & 0,20649 & \\
\hline $\mathbf{O}_{6}$ & 0,164788 & \\
\hline
\end{tabular}

The Threats factor has 6 sub-factors and the local weights for each sub-factor were calculated as seen in Table 12. Because $C R=0,029 \leq 0,10$, the obtained results are consistent. Since the weights of T1 and T2 are small at a negligible level, the related weight values were taken as zero in accordance with the fuzzy AHP procedure.

Table 12. The local weights of the Threats' sub-factors

\begin{tabular}{|c|c|c|}
\hline & $\mathbf{W}_{\mathbf{i}}$ & $\mathrm{CR}$ \\
\hline$T_{1}$ & 0 & \multirow{6}{*}{0,029} \\
\hline $\mathbf{T}_{2}$ & 0 & \\
\hline $\mathbf{T}_{3}$ & 0,214343 & \\
\hline $\mathbf{T}_{4}$ & 0,122933 & \\
\hline $\mathbf{T}_{5}$ & 0,114996 & \\
\hline$T_{6}$ & 0,547728 & \\
\hline
\end{tabular}

At the current stage, firstly Expanded SWOT analysis sub-factors should be prioritized to determine the strategies related to solar energy production. Expanded SWOT analysis sub-factors whose weights are zero are not taken into consideration as also seen in Table 9-12, since they are not important in determining the strategies. Global weights of Expanded SWOT sub-factors were found by multiplying the local weights of the related sub-factors and the weights of the factors that the sub-factors belong to. Then, as seen in Table 13, the priority ranking of Expanded SWOT analysis sub-factors was made. According to this, W1 (Its investment cost is high) appears as the highest priority sub-factor with the 0.165537 weight value. W4 (Depending on the use of solar panels used in energy production, the energy production efficiency decreases by years) appears as the lowest priority sub-factor with the 0,006837 weight value.

Step 4: Determination of the strategies which should be focused

When the priority order in Table 13 is analyzed, the ranking of the top 10 sub-factors from the most important to the less important is as follows;

$>\mathrm{W}_{1}$ : Its investment cost is high

$>\mathrm{O}_{3}$ : It can be used more widely with the rapid development of technology

$>\mathrm{W}_{5}$ : As solar energy cannot be produced continuously there is a need for storage and the storage opportunities are limited

$>\mathrm{S}_{2}$ : Transforming the sun into energy is easy

$>\mathrm{S}_{6}$ : It can be used in all areas where energy is needed

$>\mathrm{S}_{10}$ : It is sustainable

$>\mathrm{T}_{6}$ : Realization of the legal process, permissions, and project approvals in the long term

$>\mathrm{O}_{5}$ : Awareness about renewable energy has begun to occur

$>\mathrm{O}_{6}$ : There is an increase in the number of domestic engineering firms and investments made in the renewable energy sector

$>\mathrm{S}_{9:}$ Solar panels increase production power and efficiency 
Table 13. Prioritization of Expanded SWOT's sub-factors

\begin{tabular}{|c|c|c|c|c|}
\hline & $\mathbf{W}_{\text {local }}$ & $\mathbf{W}_{\text {factor }}$ & $\mathbf{W}_{\text {global }}$ & Priority \\
\hline$S_{2}$ & 0,22555 & \multirow{8}{*}{0,340883} & 0,076886 & 4 \\
\hline $\mathbf{S}_{4}$ & 0,062974 & & 0,021467 & 16 \\
\hline $\mathbf{S}_{5}$ & 0,084346 & & 0,028752 & 13 \\
\hline $\mathbf{S}_{6}$ & 0,198926 & & 0,06781 & 5 \\
\hline $\mathbf{S}_{7}$ & 0,060601 & & 0,020658 & 17 \\
\hline $\mathbf{S}_{8}$ & 0,067426 & & 0,022984 & 14 \\
\hline $\mathbf{S}_{9}$ & 0,119442 & & 0,040716 & 10 \\
\hline$S_{10}$ & 0,180736 & & 0,06161 & 6 \\
\hline $\mathbf{W}_{1}$ & 0,55018 & \multirow{5}{*}{0,300878} & 0,165537 & 1 \\
\hline $\mathbf{W}_{4}$ & 0,022722 & & 0,006837 & 22 \\
\hline$W_{5}$ & 0,274003 & & 0,082441 & 3 \\
\hline$W_{6}$ & 0,024384 & & 0,007337 & 21 \\
\hline $\mathbf{W}_{7}$ & 0,128711 & & 0,038726 & 12 \\
\hline $\mathrm{O}_{1}$ & 0,079308 & \multirow{5}{*}{0,253261} & 0,020086 & 18 \\
\hline $\mathrm{O}_{3}$ & 0,391602 & & 0,099177 & 2 \\
\hline $\mathbf{O}_{4}$ & 0,157812 & & 0,039968 & 11 \\
\hline $\mathrm{O}_{5}$ & 0,20649 & & 0,052296 & 8 \\
\hline $\mathrm{O}_{6}$ & 0,164788 & & 0,041734 & 9 \\
\hline $\mathbf{T}_{3}$ & 0,214343 & \multirow{4}{*}{0,104978} & 0,022501 & 15 \\
\hline $\mathbf{T}_{4}$ & 0,122933 & & 0,012905 & 19 \\
\hline $\mathbf{T}_{5}$ & 0,114996 & & 0,012072 & 20 \\
\hline$T_{6}$ & 0,547728 & & 0,057499 & 7 \\
\hline
\end{tabular}

As can be seen from the order above, although there are two important weaknesses the dominance of strengths and opportunities attract the attention in the top 10. Only one threat could enter the top 10 and creating strategies related to threats may not make much sense. It is noteworthy that the two weaknesses are in the top 3 and are consecutive with opportunities and strengths in the ranking. In this study, these striking information were used while creating strategies that should be focused and the strategies created are mentioned below;

SS Strategies: Strategies were developed with a focus on the following strengths but all strengths can not be used at the same time;

$\mathrm{S}_{2}$ : Transforming the sun into energy is easy

$>\mathrm{S}_{6}$ : It can be used in all areas where energy is needed

$>\mathrm{S}_{10}$ : It is sustainable

$>\mathrm{S}_{9}$ : Solar panels increase production power and efficiency

The SS strategy created using the two most important strengths $\left(\mathrm{S}_{2}\right.$ and $\left.\mathrm{S}_{6}\right)$ in the top 10 is as below; "Making it obligatory that the energy need of society in common use areas was met with the solar energy".

WW Strategies: Strategies were developed with a focus on the following weaknesses;

$\mathrm{W}_{1}$ : Its investment cost is high 
$\mathrm{W}_{5}$ : As solar energy can not be produced continuously there is a need for storage and the storage opportunities are limited

The WW strategy created using the two weaknesses $\left(\mathrm{W}_{1}\right.$ and $\left.\mathrm{W}_{5}\right)$ in the top 10 is as below;

"Supporting R\&D studies which must be made to reduce investment costs and solve energy storage problems, of the universities".

OO Strategies: Strategies were developed with a focus on the following opportunities;

$>\mathrm{O}_{3}$ : It can be used more widely with the rapid development of technology

$>\mathrm{O}_{5}$ : Awareness about renewable energy has begun to occur

$>\mathrm{O}_{6}$ : There is an increase in the number of domestic engineering firms and investments made in the renewable energy sector

The $\mathrm{OO}$ strategy created using the three opportunities $\left(\mathrm{O}_{3}, \mathrm{O}_{5}\right.$, and $\left.\mathrm{O}_{6}\right)$ in the top 10 is as below;

"Opening university-industry cooperation calls which contribute to local entrepreneurs within TÜBİTAK, providing more incentives and increasing visibility of these incentives".

SO Strategies: These are the strategies that focus on strengths $\left(\mathrm{S}_{2}, \mathrm{~S}_{6}, \mathrm{~S}_{10}, \mathrm{~S}_{9}\right)$ to take advantage of opportunities $\left(\mathrm{O}_{3}, \mathrm{O}_{5}, \mathrm{O}_{6}\right)$. But all strengths and opportunities can not be used at the same time. The SO strategy created using the one strength $\left(\mathrm{S}_{9}\right.$ : Solar panels increases production power and efficiency) and one opportunity $\left(\mathrm{O}_{6}\right.$ : There is an increase in the number of domestic engineering firms and investments made in the renewable energy sector) in the top 10 is as below;

"Encouraging domestic solar panel production and R\&D activities by the related units of the state within the framework of university-industry cooperation".

SW Strategies: These are the strategies that focus on strengths $\left(\mathrm{S}_{2}, \mathrm{~S}_{6}, \mathrm{~S}_{10}, \mathrm{~S}_{9}\right)$ to strengthen weaknesses $\left(\mathrm{W}_{1}, \mathrm{~W}_{5}\right)$. But all strengths and weaknesses can not be used at the same time. The SW strategy created using the two strengths ( $\mathrm{S}_{6}$ : It can be used in all areas where energy is needed, $\mathrm{S}_{9}$ : Solar panels increases production power and efficiency) and one opportunity ( $\mathrm{W}_{1}$ : Its investment cost is high) in the top 10 is as below;

"Encouraging the installation of solar power panels in all state-owned buildings (schools, ministries, etc.) and supporting investment costs of the state".

OW Strategies: These are the strategies that focus the opportunities $\left(\mathrm{O}_{3}-\mathrm{O}_{5}-\mathrm{O}_{6}\right)$ to eliminate the weaknesses $\left(\mathrm{W}_{1}-\mathrm{W}_{5}\right)$. But all opportunities and weaknesses can not be used at the same time. The OW strategy created using the one opportunity $\left(\mathrm{O}_{3}\right.$ : It can be used more widely with the rapid development of technology) and one weakness ( $\mathrm{W}_{5}$ : As the solar energy cannot be produced continuously there is a need for storage and the storage opportunities are limited) in the top 10 is as below;

"Encouraging university projects to develop batteries for the problem of energy storage of solar power plants".

OS Strategies: These are the strategies that focus the opportunities $\left(\mathrm{O}_{3}, \mathrm{O}_{5}, \mathrm{O}_{6}\right)$ to increase the strengths $\left(\mathrm{S}_{2}, \mathrm{~S}_{6}, \mathrm{~S}_{10}, \mathrm{~S}_{9}\right)$. But all opportunities and strengths can not be used at the same time. The OS strategy created using the one opportunity $\left(\mathrm{O}_{3}\right.$ : It can be used more widely with the rapid development of technology) and one strength ( $\mathrm{S}_{6}$ : It can be used in all areas where energy is needed) in the top 10 is as below; 
"Using e-learning materials to raise the awareness on the use of solar energy in the society and to explain how to cooperate related to the subject".

WS Strategies: These are the strategies that focus on the weaknesses $\left(\mathrm{W}_{1}, \mathrm{~W}_{5}\right)$ to increase the strengths $\left(\mathrm{S}_{2}, \mathrm{~S}_{6}, \mathrm{~S}_{10}, \mathrm{~S}_{9}\right)$. But all weaknesses and strengths can not be used at the same time. The WS strategy created using the one weakness $\left(\mathrm{W}_{5}\right.$ : As the solar energy cannot be produced continuously there is a need for storage and the storage opportunities are limited) and one strength ( $\mathrm{S}_{9}$ : Solar panels increases production power and efficiency) in the top 10 is as below;

"Opening of the project calls to meet the storage need for solar power and to increase the efficiency of solar panels".

WO Strategies: These are the strategies focusing on the weaknesses $\left(\mathrm{W}_{1}, \mathrm{~W}_{5}\right)$ to take advantage of the opportunities $\left(\mathrm{O}_{3}, \mathrm{O}_{5}, \mathrm{O}_{6}\right)$. But all weaknesses and opportunities can not be used at the same time. The WO strategy created using the one weakness $\left(\mathrm{W}_{5}\right.$ : As the solar energy cannot be produced continuously there is a need for storage and the storage opportunities are limited) and the two opportunities $\left(\mathrm{O}_{3}\right.$ : It can be used more widely with the rapid development of technology, $\mathrm{O}_{5}$ : Awareness about renewable energy has begun to occur) in the top 10 is as below;

"Raising awareness on the subject by explaining the inadequacies and needs related to solar energy storage to relevant persons and institutions using e-learning materials".

The factors and sub-factors prioritized by the fuzzy AHP method were transformed into strategies in the Expanded SWOT matrix. These strategies can be eliminated, improved, or increased according to the state's energy policies.

\section{SENSITIVITY ANALYSIS}

In this section, sensitivity analysis has been performed to see the effect of the different weights given to the SWOT factors on the strategies created. The different weights given for the SWOT factors are as in Table 14;

Table 14. The different scenarios for SWOT factors weights

\begin{tabular}{|c|c|c|c|c|}
\hline & $\begin{array}{c}\text { Scenario 1 } \\
\text { (current) }\end{array}$ & Scenario 2 & Scenario 3 & Scenario 4 \\
\hline S & 0,34 & 0,25 & 0,20 & 0,15 \\
\hline $\mathbf{W}$ & 0,30 & 0,25 & 0,30 & 0,35 \\
\hline $\mathbf{O}$ & 0,25 & 0,25 & 0,20 & 0,15 \\
\hline $\mathbf{T}$ & 0,11 & 0,25 & 0,30 & 0,35 \\
\hline
\end{tabular}

Except for the current scenario, 3 scenarios were created. As seen in Table 14, all SWOT factors were given equal weight in the second scenario. In the later scenarios (3rd and 4th scenarios), the weights of the negative factors of the SWOT (W-T) were gradually increased. As a natural consequence of this situation, it is seen that the global weights (which are in the top 10 in prioritization) chosen to determine the strategies are gradually increasing for the $\mathrm{T}$ and $\mathrm{W}$ sub-factors as seen in Table 15. Despite all this, according to the current scenario (scenario 1), only OO, SO and WS strategies change in the other 3 scenarios as seen in Table 16. At the same time, the same strategy is used for SO and WS strategies in the other 3 scenarios. Only in scenario 4, since weights of the T and W sub-factors are much, S6 which is in the 11th place, was included in the analysis. In addition, strategies can be written related to the threats for scenarios 3 and 4 . In the current scenario, threats were not included in the strategies since there is one threat at the top 10 . 
Table 15. The SWOT sub-factor weights according to different scenarios

\begin{tabular}{|c|c|l|c|l|c|l|c|c|}
\cline { 2 - 9 } \multicolumn{2}{|c|}{ Scenario 1 } & \multicolumn{3}{c|}{ Scenario 2 } & \multicolumn{3}{c|}{ Scenario 3 } & \multicolumn{3}{c|}{ Scenario 4 } \\
\hline $\mathbf{1}$ & W1 & 0,165537 & W1 & 0,137545 & W1 & 0,165054 & W1 & 0,192563 \\
\hline $\mathbf{2}$ & O3 & 0,099177 & T6 & 0,136932 & T6 & 0,164318 & T6 & 0,191705 \\
\hline $\mathbf{3}$ & W5 & 0,082441 & O3 & 0,0979 & W5 & 0,082201 & W5 & 0,095901 \\
\hline 4 & S2 & 0,076886 & W5 & 0,068501 & O3 & 0,07832 & T3 & 0,07502 \\
\hline $\mathbf{5}$ & S6 & 0,06781 & S2 & 0,056387 & T3 & 0,064303 & O3 & 0,05874 \\
\hline $\mathbf{6}$ & S10 & 0,06161 & T3 & 0,053586 & S2 & 0,04511 & W8 & 0,045049 \\
\hline $\mathbf{7}$ & T6 & 0,057499 & O5 & 0,051623 & O5 & 0,041298 & T4 & 0,043027 \\
\hline $\mathbf{8}$ & O5 & 0,052296 & S6 & 0,049732 & S6 & 0,039785 & T5 & 0,040248 \\
\hline $\mathbf{9}$ & O6 & 0,041734 & S10 & 0,045184 & W8 & 0,038613 & S2 & 0,033832 \\
\hline $\mathbf{1 0}$ & S9 & 0,040716 & O6 & 0,041197 & T4 & 0,03688 & O5 & 0,030974 \\
\hline $\mathbf{1 1}$ & O4 & 0,039968 & O4 & 0,039453 & S10 & 0,036147 & S6 & 0,029839 \\
\hline $\mathbf{1 2}$ & W8 & 0,038726 & W8 & 0,032178 & T5 & 0,034499 & S10 & 0,02711 \\
\hline $\mathbf{1 3}$ & S5 & 0,028752 & T4 & 0,030733 & O6 & 0,032958 & O6 & 0,024718 \\
\hline $\mathbf{1 4}$ & S8 & 0,022984 & S9 & 0,02986 & O4 & 0,031562 & O4 & 0,023672 \\
\hline $\mathbf{1 5}$ & T3 & 0,022501 & T5 & 0,028749 & S9 & 0,023888 & S9 & 0,017916 \\
\hline $\mathbf{1 6}$ & S11 & 0,021467 & S5 & 0,021087 & S5 & 0,016869 & S5 & 0,012652 \\
\hline $\mathbf{1 7}$ & S7 & 0,020658 & O1 & 0,019827 & O1 & 0,015862 & O1 & 0,011896 \\
\hline $\mathbf{1 8}$ & O1 & 0,020086 & S8 & 0,016856 & S8 & 0,013485 & S8 & 0,010114 \\
\hline $\mathbf{1 9}$ & T4 & 0,012905 & S11 & 0,015743 & S11 & 0,012595 & S11 & 0,009446 \\
\hline $\mathbf{2 0}$ & T5 & 0,012072 & S7 & 0,01515 & S7 & 0,01212 & S7 & 0,00909 \\
\hline $\mathbf{2 1}$ & W7 & 0,007337 & W7 & 0,006096 & W7 & 0,007315 & W7 & 0,008534 \\
\hline $\mathbf{2 2}$ & W4 & 0,006837 & W4 & 0,005681 & W4 & 0,006817 & W4 & 0,007953 \\
\hline
\end{tabular}

Table 16. Results obtained according to the sensitivity analysis

\begin{tabular}{|l|l|l|l|l|}
\hline & \multicolumn{1}{|c|}{$\begin{array}{c}\text { Scenario 1 } \\
\text { (current) }\end{array}$} & Scenario 2 & \multicolumn{1}{|c|}{ Scenario 3 } & \multicolumn{1}{|c|}{ Scenario 4 } \\
\hline SS Strategy & $\mathrm{S}_{2} \mathrm{~S}_{6}$ & $\mathrm{~S}_{2} \mathrm{~S}_{6}$ & $\mathrm{~S}_{2} \mathrm{~S}_{6}$ & $\mathrm{~S}_{2}\left(\mathrm{~S}_{6}\right)^{*}$ \\
\hline WW Strategy & $\mathrm{W}_{1} \mathrm{~W}_{5}$ & $\mathrm{~W}_{1} \mathrm{~W}_{5}$ & $\mathrm{~W}_{1} \mathrm{~W}_{5}$ & $\mathrm{~W}_{1} \mathrm{~W}_{5}$ \\
\hline OO Strategy & $\mathrm{O}_{3} \mathrm{O}_{5} \mathrm{O}_{6}$ & $\mathrm{O}_{3} \mathrm{O}_{5} \mathrm{O}_{6}$ & $\mathrm{O}_{3} \mathrm{O}_{5}$ & $\mathrm{O}_{3} \mathrm{O}_{5}$ \\
\hline SO Strategy & $\mathrm{S}_{9} \mathrm{O}_{6}$ & $\mathrm{~S}_{6} \mathrm{O}_{5}$ & $\mathrm{~S}_{6} \mathrm{O}_{5}$ & $\left(\mathrm{~S}_{6}\right)^{*} \mathrm{O}_{5}$ \\
\hline SW Strategy & $\mathrm{S}_{6} \mathrm{~W}_{1}$ & $\mathrm{~S}_{6} \mathrm{~W}_{1}$ & $\mathrm{~S}_{6} \mathrm{~W}_{1}$ & $\left(\mathrm{~S}_{6}\right)^{*} \mathrm{~W}_{1}$ \\
\hline OW Strategy & $\mathrm{O}_{3} \mathrm{~W}_{5}$ & $\mathrm{O}_{3} \mathrm{~W}_{5}$ & $\mathrm{O}_{3} \mathrm{~W}_{5}$ & $\mathrm{O}_{3} \mathrm{~W}_{5}$ \\
\hline OS Strategy & $\mathrm{O}_{3} \mathrm{~S}_{6}$ & $\mathrm{O}_{3} \mathrm{~S}_{6}$ & $\mathrm{O}_{3} \mathrm{~S}_{6}$ & $\mathrm{O}_{3}\left(\mathrm{~S}_{6}\right)^{*}$ \\
\hline WS Strategy & $\mathrm{W}_{5} \mathrm{~S}_{9}$ & $\mathrm{~W}_{5} \mathrm{~S}_{2}$ & $\mathrm{~W}_{5} \mathrm{~S}_{2}$ & $\mathrm{~W}_{5} \mathrm{~S}_{2}$ \\
\hline WO Strategy & $\mathrm{W}_{5} \mathrm{O}_{3} \mathrm{O}_{5}$ & $\mathrm{~W}_{5} \mathrm{O}_{3} \mathrm{O}_{5}$ & $\mathrm{~W}_{5} \mathrm{O}_{3} \mathrm{O}_{5}$ & $\mathrm{~W}_{5} \mathrm{O}_{3} \mathrm{O}_{5}$ \\
\hline
\end{tabular}

\section{CONCLUSIONS}

The need for energy is constantly increasing for various reasons in the world, and existing fossil resources are insufficient to meet this need. Renewable energy that the world has focused on to close this energy need deficit, has become a very popular field today. Turkey also attaches great importance to renewable energy and creates its policies related to energy planning in this direction. Because Turkey has high solar energy potential due to its geographical location, it attaches great importance to solar energy. Therefore, it 
is aimed to determine the strategies related to Turkey's solar energy production in this study. A new integrated approach called the Fuzzy Expanded SWOT consisting of Fuzzy AHP and Expanded SWOT methods, has been proposed to create the mentioned strategies. Many disadvantages of the classical SWOT analysis have been overcome with the developed method.

The strategies were created with the sub-factors that ranked in the top 10 after the prioritization made based on the weights of the sub-factors. Strategies were created based on Strengths, Weaknesses, and Opportunities with the thought that threats can be neglected since there is only one threat in the top 10 . Therefore, strategies created according to the Expanded SWOT matrix are SS, WW, OO, SO, SW, OW, OS, WS, and WO strategies. Since the weights of threats were low, no strategies related to the threats (ST, WT, OT, TS, TW, TO, TT) in the Expanded SWOT matrix were created in this study. The issue which draws attention in the priority ranking of Expanded SWOT sub-factors is that the weaknesses come into prominence. Therefore, the strategies which come into prominence among the created strategies are related to the weaknesses and are as follows;

$>$ WW Strategy: Supporting R\&D studies which must be made to reduce investment costs and solve energy storage problems, of the universities.

$>$ SW Strategy: Encouraging the installation of solar power panels in all state-owned buildings (schools, ministries, etc.) and supporting investment costs of the state.

$>$ OW Strategy: Encouraging university projects to develop batteries for the problem of energy storage of solar power plants.

$>$ WS Strategy: Opening of project calls to meet the storage need for solar power and to increase the efficiency of solar panels.

$>$ WO Strategy: Raising awareness on the subject by explaining the inadequacies and needs related to solar energy storage to relevant persons and institutions using e-learning materials.

The strategies which should be dwelled on related to solar energy production in Turkey, are ones which concentrate on R\&D studies in public institutions, the private sector, and universities. Of course, it is necessary to emphasize the importance of performance-based selecting and evaluating of R\&D studies and projects.

As a result of the sensitivity analysis for the proposed model, it was seen that the weights of the SWOT factors changed the direction of the strategies. More clearly, the weights of the SWOT factors play an active role in determining the global weights and priority order. In this case, strategies are formed from the SWOT sub-factors which are in the first places (with higher priority). Accordingly, as seen in Table 14 in the analysis, when the weights of $\mathrm{W}$ and $\mathrm{T}$ factors are increased in scenarios 3 and 4, the weights of $\mathrm{W}$ and $\mathrm{T}$ sub-factors also increase in the ranking as seen in Table 15. For scenarios 3 and 4, appropriate strategies can be added related to the weaknesses (WW, WT\&TW) and threats (TS\&ST, TW\&WT, TO\&OT, TT).

As a result, in this study, the analysis values were obtained by taking the valuable information of the experts who worked as engineers and managers in solar energy projects for more than 10 years to determine the solar energy strategies for Turkey. Here, it is important work that has been put into practice to transform the qualified implicit knowledge of the experts into explicit knowledge, to include them in the analysis, and to draw conclusions. The limitation of the study is that the evaluations are made according to the expert opinions, this situation may create subjectivity in the study. In future study, the determination of strategies can be done by presenting alternative strategies with an artificial intelligence algorithm. 


\section{REFERENCES}

[1] Lund, H. (2010). Renewable energy systems: The choice and modeling of $100 \%$ renewable solutions. USA: Academic Press,

[2] International Renewable Energy Agency (IRENA), "Solar Energy", https://www.irena.org/solar/, Accessed: 30/03/2020.

[3] Republic of Turkey Ministry of Energy and Natural Resources, "Solar Energy", https://www.enerji.gov.tr/tr-TR/Sayfalar/Gunes/, Accessed: 30/03/2020.

[4] International Energy Agency (IEA), "Total Primary Energy Supply for the World", https://www.iea.org/world/, Accessed: 12/01/2020.

[5] International Energy Agency (IEA), "Total Primary Energy Supply for the Europe", https://www.iea.org/regions/europe/, Accessed: 12/01/2020.

[6] Dönmez, F., 7. “Anadolu Güneşi Elektrik Üretiyor Kayseri Buluşması”, https://www.aa.com.tr/tr/politika/enerji-ve-tabii-kaynaklar-bakani-donmez-turkiye-bugun-yenilenebilirenerji-kurulu-gucunde-avrupada-altinci/1741509/, Accessed: 13/03/2020.

[7] Kajanus, M., Kurttila, M.,\& Pesonen, M. (1996). Applying SWOT and AHP analysis when changing to eco-labeled forestry, Integrating Environmental Values into Forest Planning-Baltic and Nordic Perspectives. The Nordic-Baltic Research Course, Räpinä, Estonia.

[8] Kangas, J., Pesonen, M., Kurttila, M.,\& Kajanus, M. (2001). A'WOT: Integrating the AHP with SWOT Analysis. 6th International Symposium on the Analytic Hierarchy Process (ISAHP), Berne, Switzerland.

[9] Kurttila, M., Pesonen, M., Kangas, J.,\& Kajanus, M. (2000). Utilizing the Analytic Hierarchy Process (AHP) in SWOT analysis - A hybrid method and its application to a forest-certification case, Forest Policy and Economics, 1(1), 41-52.

[10] Shrestha, R.K., Alavalapati, J.R.,\& Kalmbacher, R.S. (2004). Exploring the potential for silvopasture adoption in south-central Florida: An application of SWOT-AHP method, Agricultural Systems, 81(3), 185-199.

[11] Yüksel, İ.,\& Dağdeviren, M. (2007). Using the Analytic Network Process (ANP) in a SWOT analysis - A case study for a textile firm, Information Sciences, 177(16), 3364-3382.

[12] Kahraman, C., Demirel, N.C.,\& Demirel, T. (2007). Prioritization of e-government strategies using a SWOT-AHP analysis: The case of Turkey, European Journal of Information Systems, 16(3), 284-298.

[13] Arslan, O.,\& Turan, O. (2009). Analytical investigation of marine casualties at the Strait of Istanbul with SWOT-AHP method, Maritime Policy \& Management, 36(2), 145-131.

[14] Taleai, M., Mansourian, A.,\& Sharifi, A. (2009). Surveying general prospects and challenges of GIS implementation in developing countries: A SWOT-AHP approach, Journal of Geographical Systems, 11 (3), 291-310.

[15] Wickramasinghe, V.,\& Takano, S.E. (2010). Application of combined SWOT and Analytic Hierarchy Process (AHP) for tourism revival strategic marketing planning, Journal of the Eastern Asia Society for Transportation Studies, 8, 954-969. 
[16] Zavadskas, E.K., Turskis, Z.,\& Tamosaitiene, J. (2011). Selection of construction enterprises management strategy based on the SWOT and multi-criteria analysis, Archives of Civil and Mechanical Engineering, 11(4), 1063-1082.

[17] Azimi, R., Yazdani-Chamzini, A., Fouladgar, M.M., Zavadskas, E.K.,\& Basiri, M.H. (2011). Ranking the strategies of mining sector through anp and topsis in a swot framework, Journal of Business Economics and Management, 12(4), 689-670.

[18] Gao, C.Y.,\& Peng, D.H. (2011). Consolidating SWOT analysis with nonhomogeneous uncertain preference information, Knowledge-Based Systems, 24(6), 808-796.

[19] Kajanus, M., Leskinen, P., Kurttila, M.,\& Kangas, J. (2012). Making use of MCDS methods in SWOT analysis - Lessons learnt in strategic natural resources management, Forest Policy and Economics, $20,1-9$.

[20] Stainback, G.A., Masozera, M., Mukuralinda, A.,\& Dwivedi, P. (2012). Smallholder agroforestry in Rwanda: A SWOT-AHP analysis, Small-Scale Forestry, 11(3), 285-300.

[21] Şeker, Ş.,\& Özgürler, M. (2012). Analysis of the Turkish consumer electronics firm using SWOTAHP method, Procedia-Social and Behavioral Sciences, 58, 1544-1554.

[22] Görener, A., Toker, K.,\& Ulucay, K. (2012). Application of combined SWOT and AHP: A case study for a manufacturing firm, Procedia-Social and Behavioral Sciences, 58, 1525-1534.

[23] Eslamipoor, R.,\& Sepehriar, A. (2014). Firm relocation as a potential solution for environment improvement using a SWOT-AHP hybrid method, Process Safety and Environmental Protection, 92(3), 276-269.

[24] Abdel-Basset, M., Mohamed, M.,\& Smarandache, F. (2018). An extension of neutrosophic AHPSWOT analysis for strategic planning and decision-making, Symmetry, 10(4), 116-133.

[25] Ghazinoory, S., Esmail Zadeh, A.,\& Memariani, A. (2007). Fuzzy SWOT analysis, Journal of Intelligent \& Fuzzy Systems, 18(1), 99-108.

[26] Kheirkhah, A.S., Esmailzadeh, A.,\& Ghazinoory, S. (2009). Developing strategies to reduce the risk of hazardous materials transportation in Iran using the method of fuzzy SWOT analysis, Transport, 24(4), $325-332$.

[27] Hosseini-Nasab, H., Hosseini-Nasab, A.,\& Milani, A.S. (2011). Coping with imprecision in strategic planning: A case study using fuzzy SWOT analysis, IBusiness, 3, 23-29.

[28] Sevkli, M., Oztekin, A., Uysal, O., Torlak, G., Turkyilmaz, A.,\& Delen, D. (2012). Development of a fuzzy ANP based SWOT analysis for the airline industry in Turkey, Expert systems with Applications, $39(1), 14-24$.

[29] Yapici Pehlivan, N., Şahin, A., Zavadskas, E.,\& Turskis, Z. (2018). A comparative study of integrated FMCDM methods for evaluation of organizational strategy development, Journal of Business Economics and Management, 19(2), 360-381.

[30] Kumar, A., Sah, B., Singh, A.R., Deng, Y., He, X., Kumar, P.,\& Bansal, R.C. (2017). A review of multi-criteria decision making $(\mathrm{MCDM})$ towards sustainable renewable energy development, Renewable and Sustainable Energy Reviews, 69, 596-609. 
[31] Terrados, J., Almonacid, G.,\& Hontoria, L. (2007). Regional energy planning through SWOT analysis and strategic planning tools: Impact on renewables development, Renewable and Sustainable Energy Reviews, 11(6), 1275-1287.

[32] Catron, J., Stainback, G.A., Dwivedi, P.,\& Lhotka, J.M. (2013). Bioenergy development in Kentucky: A SWOT-ANP analysis, Forest Policy and Economics, 28, 38-43.

[33] Kabak, M.,\& Dağdeviren, M. (2014). Prioritization of renewable energy sources for Turkey by using a hybrid MCDM methodology, Energy Conversion and Management, 79, 25-33.

[34] Adar, E., Karatop, B., İnce, M.,\& Bilgili, M.S. (2016). Comparison of methods for sustainable energy management with sewage sludge in Turkey based on SWOT-FAHP analysis, Renewable and Sustainable Energy Reviews, 62, 429-440.

[35] Kabak, M., Dağdeviren, M.,\& Burmaoğlu, S. (2016). A hybrid SWOT-FANP model for energy policy making in Turkey, Energy Sources, Part B: Economics, Planning, and Policy, 11(6), 487-495.

[36] Sindhu, S., Nehra, V.,\& Luthra, S. (2017). Solar energy deployment for sustainable future of India: Hybrid SWOC-AHP analysis, Renewable and Sustainable Energy Reviews, 72, 1138-1151.

[37] Ervural, B.C., Zaim, S., Demirel, O.F., Aydin, Z.,\& Delen, D. (2018). An ANP and fuzzy TOPSISbased SWOT analysis for Turkey's energy planning, Renewable and Sustainable Energy Reviews, 82, $1538-1550$.

[38] Khan, M.I. (2018). Evaluating the strategies of compressed natural gas industry using an integrated SWOT and MCDM approach, Journal of Cleaner Production, 172, 1035-1052.

[39] Solangi, Y.A., Tan, Q., Mirjat, N.H.,\& Ali, S. (2019). Evaluating the strategies for sustainable energy planning in Pakistan: An integrated SWOT-AHP and Fuzzy-TOPSIS approach, Journal of Cleaner Production, 236, 117655.

[40] Alizadeh, R., Soltanisehat, L., Lund, P.D.,\& Zamanisabzi, H. (2020). Improving renewable energy policy planning and decision-making through a hybrid MCDM method, Energy Policy, 137, 111174.

[41] Kuo-liang, L.,\& Shu-chen, L. (2008). A fuzzy quantified SWOT procedure for environmental evaluation of an international distribution center, Information Sciences, 178(2), 531-549.

[42] Kahraman, C., Cebeci, U.,\& Ulukan, Z. (2003). Multi-criteria supplier selection using fuzzy AHP, Logistics Information Management, 16(6), 382-394.

[43] Toksarı, M.,\& Toksarı, M.D. (2011). Bulanık Analitik Hiyerarşi Prosesi (AHP) yaklaşımı kullanılarak hedef pazarın belirlenmesi, ODTÜ Gelişme Dergisi, 38(1), 51-70.

[44] Chang, D.Y. (1996). Applications of the extent analysis method on fuzzy AHP, European Journal of Operational Research, 95(3), 649-655.

[45] Learned, E.P., Christensen, C.R., Andrews, K.E.,\& Guth, W.D. (1965). Business policy: Text and cases. Irwin: Homewood.

[46] David, F.R. (2007). Strategic management concepts and cases. New York: Prentice Hall,.

[47] Hill T.,\& Westbrook, R. (1997). SWOT analysis: It's time for a product recall, Long Range Planning, $30(1), 46-52$. 
[48] Karatop, B., Kubat, C.,\& Uygun, Ö. (2018). Determining the strategies on Turkish automotive sector using fuzzy AHP based on the SWOT analysis, Sakarya Üniversitesi Fen Bilimleri Enstitüsü Dergisi, 22 (5), 1314-1325. 